\title{
Singapore as a Creative City: vignettes from the perspective of la flâneuse tropique
}

\author{
Sneha Chaudhury
}

James Cook University Singapore

Anita Lundberg

James Cook University Singapore

\begin{abstract}
The tropical metropolis of Singapore is on a quest to become a creative city. Its policies explicate the need to transform into a 'renaissance city', a global hub of creative industries and economies. Yet, for Singapore - better known for its panoptic rather than creative imaginary - the question remains 'how does the government's policy of creativity translate on the ground?' As a theory and method of critically meandering through the city in order to participate and observe quotidian practices at the street level, flânerie offers a way of engaging and contributing to an ethnography of urban life. This paper explores flânerie through the perspective of the female flâneuse. Two vignettes - one concerning heritage and the other graffiti - provide thick descriptions of encounters with creative practices in Singapore.
\end{abstract}

Keywords: ethnographic flânerie, flâneur, flâneuse, creative cities, Singapore, heritage, graffiti 


\section{Cities in Creative Transition}

I

$\mathrm{t}$ is common knowledge that Singapore is considered to be run like a giant corporation. For this reason, Singapore rarely comes to mind when talking about arts, culture and creativity, and its ambitions to become a creative city have been heavily contested, debated and critiqued. The unofficial opinion is that the city does not have what it takes to be anything more than a commercial hub. However, the government is striving to change this imaginary and has put policies in place in order to transform Singapore into a 'distinctive global city for the arts' (MICA 2008, p.6). The 'Renaissance City Plan' designed in three stages from 2000-2015 was to strategically chart the transition of Singapore into a creative metropolis by benchmarking itself against cities such as New York, London, Melbourne and Hong Kong (MICA, 2008).

On the one hand, the Renaissance City Plan demonstrates the government's foresight and drive to make Singapore one of the most competitive destinations in the world. On the other hand, it exposes a shortsightedness regarding the cultivation of a culture of creativity. Furthermore, benchmarking Singapore against arts capitals - primarily in the West - exposes the dichotomy of wanting to create a culturally unique space by emulating others. In short, the Renaissance City Plan aims to socially engineer a creative city.

Singapore's creative city plan is based in a pragmatic economic standpoint. To stay relevant in a global context it needs to continue to draw on human resources and to invest in creative industries and economies where there is a high added value to products - and in this regard, the government of Singapore has identified creative societies as multi-billion dollar industries. However, gauging creativity as an economic activity or merely as industry puts Singapore's plan in a precarious situation. Critics point out that the mechanisms enabling this creativity to radiate out or 'trickle down' to the citizenry - and even more importantly be created by the people - are never clearly identified. In short, while the panoptic view provides a blueprint plan for the city's art and culture, its translation on the ground level is not clear. In her paper 'Ambitions of a Global City: Arts, Culture and Creative Economy in "Post-Crisis" Singapore', Lilly Kong, explains:

For the arts and culture and creative industries to flourish and for Singapore to develop a nation of cultural consumers, and more than that, a nation of cultured people, visitorships and attendances at cultural 
events may provide useful indicators but cannot capture the sense of a larger milieu, one that values and is steeped in culture. For that, there is need for a gamut of supporting instruments to develop the appetite and critical appreciation of consumers.... This is premised on the principle that "art does not, and cannot, exist in a vacuum; the works of artists must be assessed from an aesthetic and historical perspective." At the moment, Singapore still lacks such a milieu (2012, p. 293).

The problem addressed in this paper pertains to whether Singapore government's top down vision and plans translate into making a creative city on the ground involving the inputs of local people and culture. In other words, can this imaginary create a vibrant expression of Singapore's sense of place? Without a sense of place, 'creative cities' incur the risk of becoming open-air museums. As Hilary du Cros and Lee Jolliffe summarise:

It has been observed by several authorities that grand government-led revitalization projects using arts as a focus have stifled or been unsuccessful in enhancing the local character of art production.... Because they lack a grassroots-up foundation, they enhance the feeling of 'placelessness' or the 'every city looks the same' syndrome (2014, p.4).

Singapore is readily cast as being guilty of such a grand revitalization or renaissance scheme; a planned, conscious effort to reimagine itself as a creative city. However, one of the objectives of this research has been to set aside any prejudice derived from the notion of Singapore as an engineered space, and instead, experience what the city has to offer beyond institutionally prescribed definitions of creativity.

Thus this paper aims to engage with the city going through this creative transition on the ground level. It does this through the theory and method of the flâneur, which, in very simple terms, means strolling in a locale to experience it, being both an observer gazing at everything happening around and simultaneously participating in the change. The theory of the flâneur originated in Paris in the early twentieth century when that city was undergoing massive architectural, structural and infrastructural changes; similar to the changes Singapore is undergoing today. 


\section{Flâneur/Flâneuse}

The notion of the flâneur has a long and esteemed history from classical texts of Charles Baudelaire (1964) and Walter Benjamin (2003) to contemporary commentaries. We have previously published a literature review that summarises important texts (Chaudhury \& Lundberg, 2018). However, the theory also warrants critique, firstly in regards to the geographical location of the cities studied, which are prominently located in the northern metropoles such as Paris, London and New York; and secondly in regards to gender, for the theory of the flâneur supports a masculine subjectivity and gaze. This research project addresses these critiques by studying a city in the tropics from the perspective of the female flâneuse; what we have termed, la flâneuse tropique.

The difference between the flâneur and flâneuse is itself entwined with the city, for the gendering of space remains an actuality of the metropolitan milieu. As flânerie requires a certain level of anonymity and the ability to wonder freely, it has been argued that it is not possible for a woman to be a flâneur. Women are still constricted within prescribed areas of the city; straying outside acceptable realms is to risk one's reputation or risk personal violence. Today in the $21^{\text {st }}$ century, women in some cities, may no longer be openly subjugated; but even for these women, their sense of agency is still under the purview of patriarchal power structures and woman is not liberated in either a mental or corporeal sense. Thus, currently, the standards that apply to a flâneur cannot be applied to the flâneuse; thereby a woman cannot actually be a flâneur and must subscribe to separate standards to engage in flânerie. Despite these challenges, women are nevertheless sentient aspects of the urban space. They are embodied pedestrians; different to the detached flâneur. La flâneuse negotiates a hybrid space. (Chaudhury \& Lundberg, 2018, pp.82-83).

The different social and cultural standards that impact upon gendered bodies and subjectivities in terms of flâneuring is essential to keep in mind when invoking the theory and practice flânerie as a form of ethnographic method to creatively explore the metropolis.

\section{Ethnographic Flânerie}

Ethnography is noted for its engagement a plethora of qualitative methods to observe social practices and interactions. Flânerie provides an added perspective to the ethnographic method of participant observation, especially in the changing cityscape 
where its engagement as a specific way of "gathering stories 'from below' or the 'street level perspective' (de Certeau, 1984), opens up a series of spaces for critical reflections on what constitutes urban life and cities" (Yi'En, 2014, p.212).

Walking through the city observing and experiencing the everyday creative practices of local and international people at the ground level enables the ethnographer-flâneuse to gauge Singapore's transformation as a creative city. Detailed notes were kept of these meanderings through the city's art precincts and creative corners. The notes, along with photographs, aided the processes of post-flâneuring reflection and discussion, which, in turn helped to write a richer description of the ethnographic flânerie.

The following map of Singapore indicates the art precincts where flânerie was carried out. The Downtown and Bay areas of Singapore have the highest concentration of institutionally prescribed, international and local centers of art. The Singapore Tourism Board prescribes a four-day itinerary to experience the arts and culture in Singapore, which is largely restricted to the Downtown and Bay areas. Part of the process of flâneuring was to explore the arts and culture related events and activities that grow in between these institutionally prescribed centers.

While utilizing a map to plan flânerie may seem counter-intuitive to the theory's nonprescribed methodology, the map nevertheless serves to demarcate the locations that are under the purview of the vision of the government in terms of the portrayal of arts and culture. Keeping this in mind, the objective of this paper has been to identify creativity which flourishes on the ground level, between 'the cracks in the sidewalk'. Those local enactments of creativity or creative interaction that cannot be captured by the panoptic gaze.

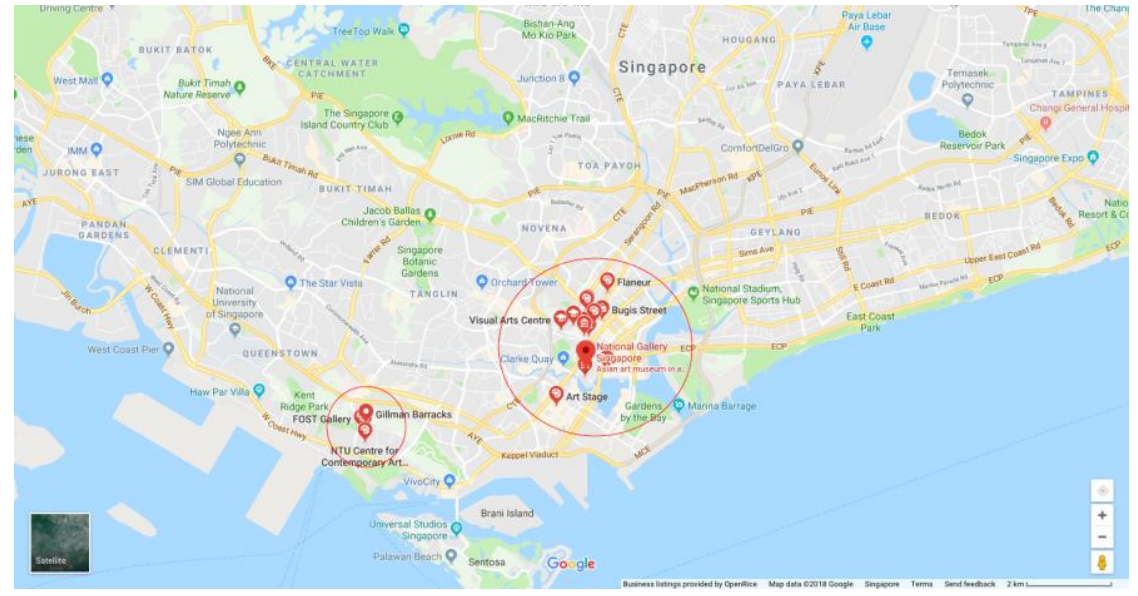

Figure 1. The areas circled in red on the map of Singapore indicate the art precincts where flâneuring took place. The circled areas, which are the bay area and downtown, have a high concentration of galleries, art schools and museums. 
This qualitative method of ethnographic-flânerie was applied over ten weeks of urban fieldwork, and observations of numerous events were carried out and recorded. For the purpose of this paper, however, we have narrowed the focus to two vignettes which have been chosen for their representative quality from a larger range of case studies of arts and cultural practices in Singapore.

\section{Ethnographic Vignettes}

Peregrinations through the designated art precincts of Singapore lead to the uncovering of several hidden gems of creativity through 'cracks in the sidewalk'; some were large events attracting scores of visitors and some were underappreciated lucky finds. These acts of flânerie were not just restricted to the act of walking through the streets but were aided by habitual usage of social media and idle conversations with people which allowed us to stumble upon events and places. The following two vignettes - which themselves were initially aroused through social media and conversation - present examples of ethnographic flânerie in the form of a heritage walk and an example of street art.

Both vignettes are written from the perspective of the authors as females flâneur-ing in the tropical city of Singapore and are offered as initial contributions to the notion of la flâneuse tropique.

\section{Vignette One: OH! Emerald Hill}

True to the tropical nature of Singapore's weather, it rained. It poured. Emerald Hill is nestled behind the famous shopping district of Orchard Road - the one-stop shopping destination for South East Asia's rich and famous. Just around the corner from the din of hypermodernity and consumerism, Emerald Hill is actually a street of Peranakan houses; these houses are symbolic of an opulent amalgam of history that forms the Peranakan culture. The anthropologist Patricia Ann Hardwick (2008) explains:

Peranakan culture combines southern Chinese and Malay traditions and is unique to the nations of Singapore, Malaysia, and Indonesia. Peranakan identity began to emerge in the seventeenth century and flourished under the British administration of the Straits Settlements and British Malaya in the late nineteenth and early twentieth centuries. Associated with the British colonial system, Peranakan identity was suppressed by early Singaporean nationalists. Aspects of Peranakan 
identity like Peranakan material culture are currently celebrated by the Singaporean nation as emblems of its unique past (Hardwick, 2008, p. 36)

The Peranakan homes were also symbolic of the growing affluence in Singapore in the early 1900s. The two-to-five storey houses are vibrant, displaying culturally eclectic ornamentation including Malay roof eaves, Malay and Chinese carvings and ornamentation, as well as Peranakan wall and floor tiles which combine colonial European with local design elements. The buildings at Emerald Hill, which range from two to three storeys, form a continuous row separated by common party walls. On one side of the street they feature small front courtyards, while on the other side, all the house fronts are linked by a sheltered walkway, locally known as 'kaki lima' (Malay) meaning 'five foot way'. Narrow and tall on the outside, the houses are surprisingly spacious on the inside in order to accommodate large joint families; a way of living which was common throughout South East Asia.

What we thought was going to be a walk in and out of these Peranakan homes to admire their architectural features turned out to be something else. The meeting point was Chatsworth International School which lies in the grounds of a former mansion, which has been converted into an IB (International Baccalaureate) school.

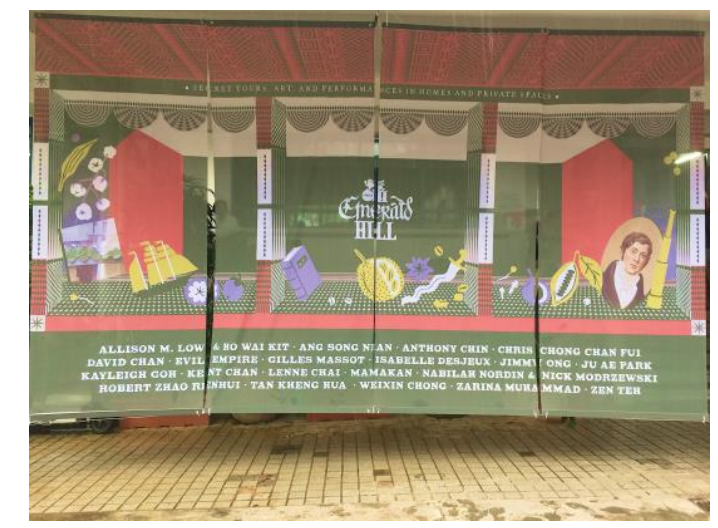

Figure 2. Event banner at the entrance of the school

At the entrance to the school, we were greeted by a barber shop quartet; three Western men and one woman dressed up in mock 'colonial' garb singing parodies about colonial life. This quartet engaged in leading hourly group tours down the busy Orchard Road to a complex called Orchard Plaza. However, the rain was a dampener and for now, people seemed content with watching the performance under the sheltered entrance. 
Entering into the school we were directed to climb the narrow wet stairs, which opened into a large auditorium bustling with volunteers and eager visitors. Hanging from the ceiling were muslin curtains. People made their way through these large curtains with their printed scenes of British rule - overlords and labourers on plantations, large game hunting, portraits of English gentlemen - serving to foreshadow the tours that lay ahead. Moving through the curtains you reached the sign-up point with green T-shirted volunteers were in attendance. As the other two tours were full we went behind the curtain displaying the photograph of plantations and signed up for the nutmeg tour.

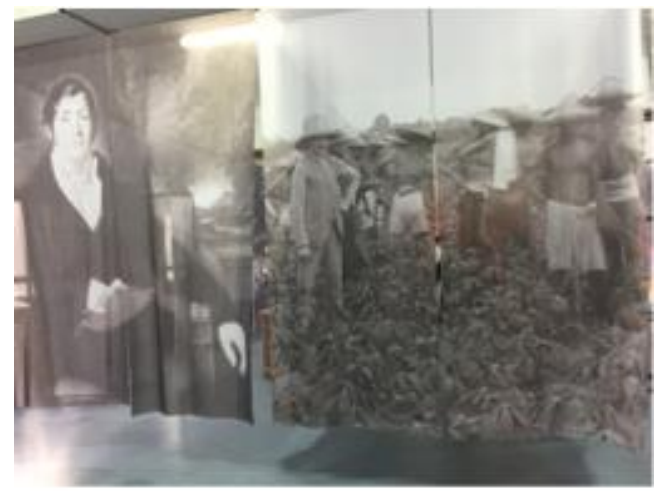

Figure 3. Curtains depicting scenes from the British rule. (Sir Stamford Raffles; scene from the nutmeg plantations)

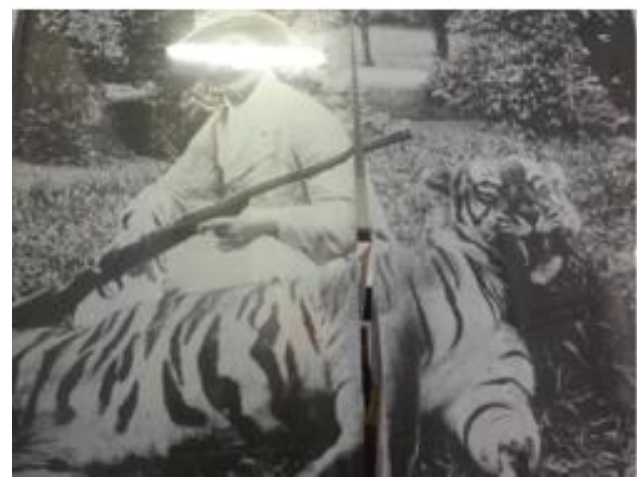

Figure 4. Scene of hunting. Colonial hunter and shot tiger.

While waiting for the tour to start, we chatted with the guide - a local Singaporean who had previously lived for several years in London. This was her first year as a volunteer and when she heard it was an open house, she had thought it would be like the ones in London, where you peer inside the Queen's palace or the Houses of Parliament. But this experience had proven quite different. As we were about to find out, it was no regular heritage walk.

Our group was small, consisting of a retired couple, a family of three, an artist from LASALLE College of the Arts (who had contributed to one of the other installations for the heritage trail), an elderly lady, as well as ourselves representing two female expats - an Indian graduate student and an Australian Academic. With umbrellas in hand, we set out. The heavy rain did not to seem to dampen anyone's enthusiasm. 


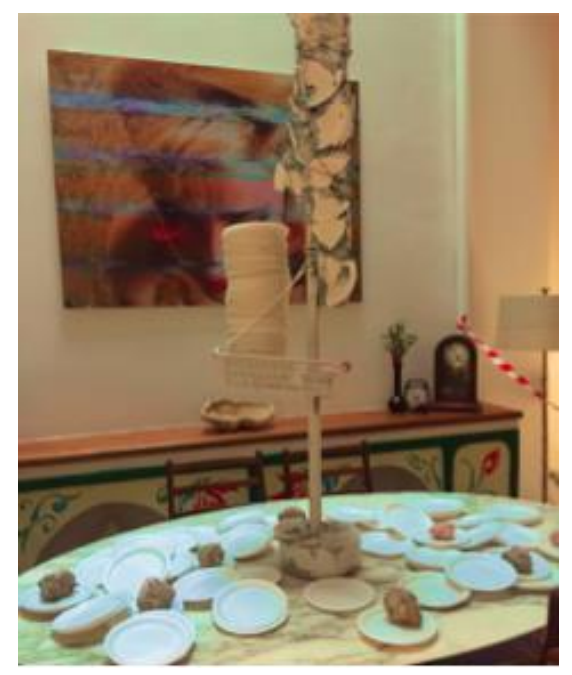

Figure 5. Inside first Peranakan house; installation depicting ships used to export nutmeg to the West.

At our first stop, a Peranakan home about a hundred meters from the school, we waited outside in the narrow courtyard. On the front doormat were signs of the private lives of the people who lived in the house - a child's bicycle abandoned among visitors' shoes. When the group before us came out, we entered in an orderly line - which struck us as being very "Singaporean"; the city is well known (and often satirized) for its conspicuous practice of queueing.

The foyer had been designed to resemble a 'godown' (etymology Tamil and Portuguese) or old warehouse for storing nutmeg. Plaster of Paris boulders arranged in a disorderly fashion made the foyer seem narrower. Meant to resemble rocks, the installations were ironically extremely fragile; and the group was forewarned not to touch the displays. In the background, an old recording machine filled the room with the sounds of an anthropomorphized nutmeg telling the tale of the British colonisers and their brazen rise to power in the East based on the fertile soils of the Malay Archipelago. A subtle scent of nutmeg filled the room. The artists had made sure to curate experiences for the various senses. To add to the experience, the exhibition was set against the private art collection of the houses' owners. Artworks, furniture, objets d'art and a floor to ceiling wall motif provided an insight into the tastes of the inhabitants. However, for the few weekends of the $\mathrm{OH}$ ! Emerald Hill tours, the house became the imaginative property of Mr William Cuppage, the first British owner of nutmeg plantations in the area. Thus, this first house depicted the rise of British rule, and the theme inspiring the art works was the profitable nutmeg plantations started by European colonists in the early 19th century after Sir Stamford Raffles sent nutmeg and clove seeds to Singapore. The nutmeg plantations in this area took over land previously 
cultivated with gambier and pepper by local Chinese farmers. However, as we were to discover, the next house would interrupt this story of empire.

Our group headed back out into the rain, crossing the road to a tight row of Peranakan houses linked by a common 'Five foot way'. Again we took off our shoes at the door. Entering the foyer, our progress was interrupted by a massive $4.9 \mathrm{~m}$ high sculpture of a colonial-style black boot that filled the entire room. This time, rather than keeping hands off, we were invited to touch the sculpture and apply slight pressure, whereupon the black turned to gold beneath our palms and our hands smelt of nutmeg. This installation was meant to signify the subjugation of colonial peoples under the pervasive power of the coloniser - and the economic incentive fueling colonialism.

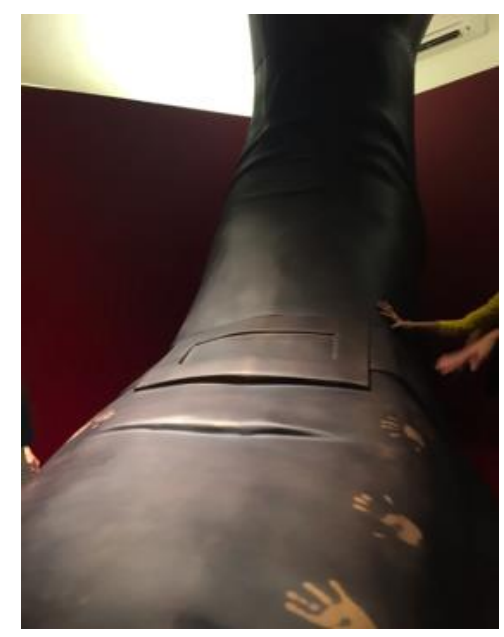

Figure 6. Inside second Peranakan home; giant boot installation.

Walking into the next room, we maneuvered around the owner's dining table and chairs to face a large glass window that looked into the study. The window was set up as a diorama exhibiting objects and photographs that symbolized the 'exotic' East and the colonial exploitation of nature, culture and humans. Tropical imaginaries of plantations, tigers, hunting, tribal peoples and exotic flora and fauna were displayed behind the window. 


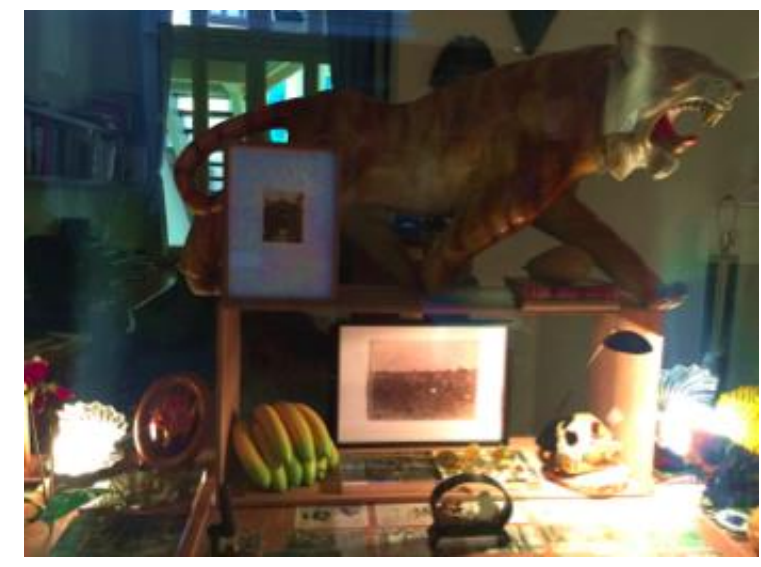

Figure 7. Inside second Peranakan home. Diorama depicting symbols of the exotic East and colonial oppression.

Silently making our way further into the house, we were led down a narrow staircase into the basement to an installation of a giant beetle lying dead on its back. Tied to the beetle were red threads that came all the way down from the three-storey high ceiling. Next to the dead beetle was an even smaller room with projected images of sick and dying children. All of this solemn imagery represented the destruction and disease caused by the beetles that infected the nutmeg plantations which ultimately led to the decimation of plantations across the island. The red strings tied to the beetle were symbolic of the red threads given to mourners at Chinese funerals - which are always dropped as a mourner leaves the funeral to ensure that they do not carry away negative energies. As we traced our steps back up the stairs, an elderly retired Singaporean lady exclaimed "If only we had been taught history like this. I don't think I'll ever forget this." People nodded and started talking, expressing their active interest - participating. Chatting we made our way upstairs to the kitchen where we were accosted with modern day appliances and a bowl of cat feed; signs of everyday life. 


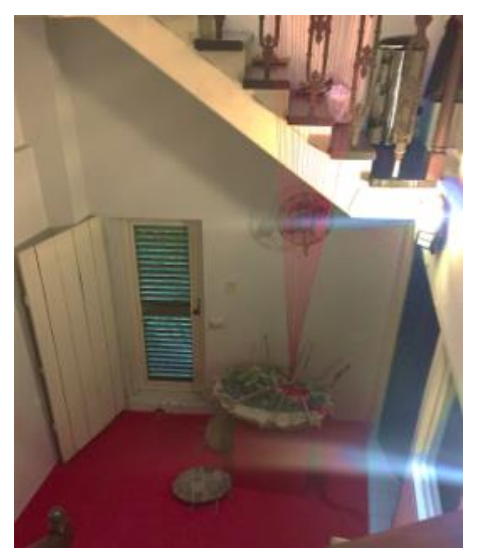

Figure 8. Inside second Peranakan home; view of the 'dead' beetle and red threads from on top of the staircase.

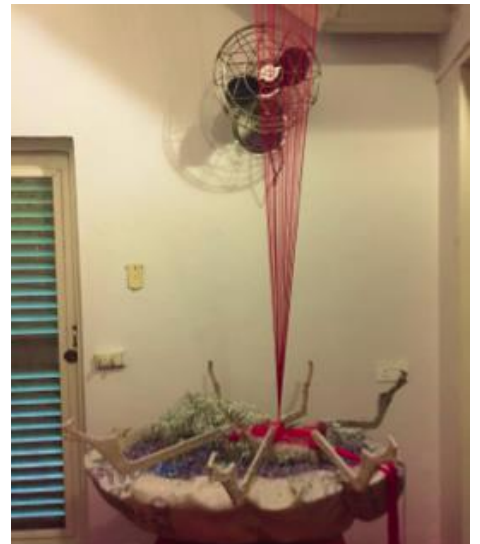

Figure 9. Inside second Peranakan home; closer view of the beetle.

This was the end of the tour. Outside the rain was temperamental. We walked back to the Chatsworth School to find the crowd had significantly increased. Undeterred by the rain, people kept streaming in, some with bands around their wrists showing the number of tours they had completed; others with no bands waiting to see what queuing up behind the various muslin curtains would reveal. The volunteers did not seem overwhelmed by the crowds in the auditorium, instead they just seemed happier to help. But we decided to break away from the regular tours and make our way to the other site of the heritage walk by ourselves. Following the trail map handed out by the organisers, we walked down the short Emerald Hill lane to Orchard Road. Suddenly we were surrounded by the spaces of consumerism - large and expensive shopping malls grandly rising on both sides of the road. Normally this area is filled with pedestrians and traffic, but the rain had driven everyone to seek shelter so the footpath seemed empty and the main road rather desolate. We consulted the map to get our bearings and then made our way down the street to Orchard Plaza, an older shopping complex lacking the glitz and glamour of the newer steel and glass structures of this prestigious shopping precinct. Once inside the plaza we meandered through the maze of quaint shops beauty parlors, travel agents and feng shui specialists - to the elevator.

On the fourth floor we approached the map's indicated point of interest. It was a real estate agency with bright yellow walls. This turned out to be an installation and commentary on the commodification of heritage in Singapore. The extremely realistic shop front had photographs of Peranakan houses for sale, it was otherwise quite bare, with a few artworks depicting terrace house fronts and a table on which stood a table lamp lighting up an imitation of a gold brick - a reference to the real estate office's name 
‘Gold Gold'.

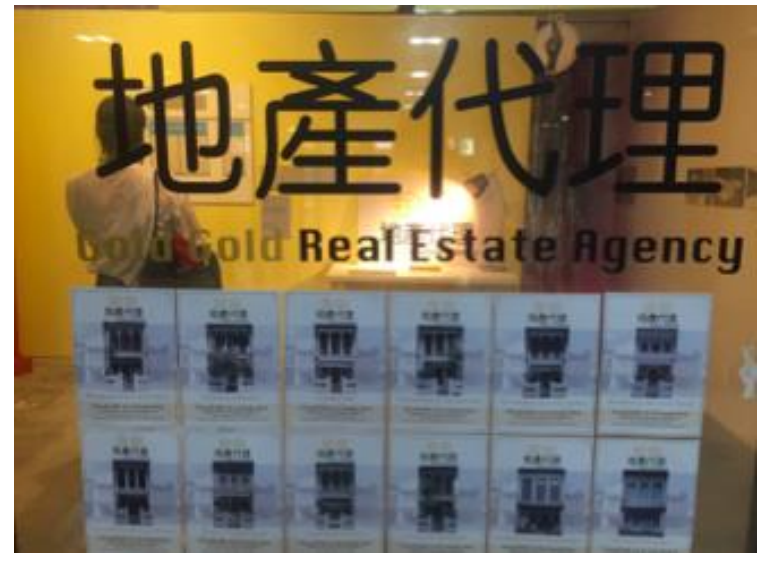

Figure 10. 'Real Estate' office installation depicting Peranakan houses "for sale".

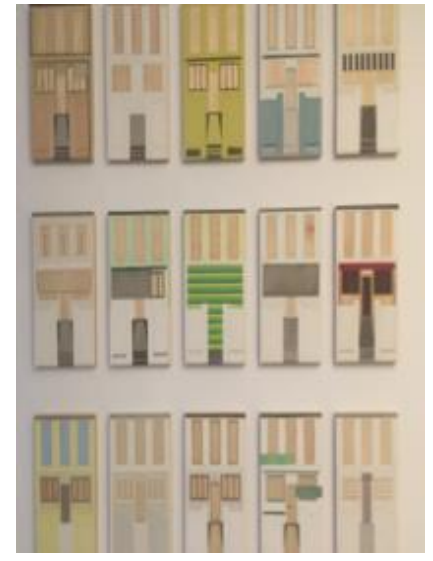

Figure 11. Inside the real estate agency installation; the front of shop houses and Peranakan homes painted on wooden blocks.

Higher up on the fifth floor our map indicated another exhibition, this was a teashop with a very low ceiling. It was designed by an artist collective to give viewers an insight into the history of the tea and how the colonisers profited heavily from this trade. Sketches of tea-associated images were displayed along the walls. The shop was also selling four distinct blends of tea with ironic names - 'Oolong Oppression', 'Stolen Scents', 'Oriental Persuasion' and 'Her Majes-Tea' made by tea merchant Pek Sin Choon.

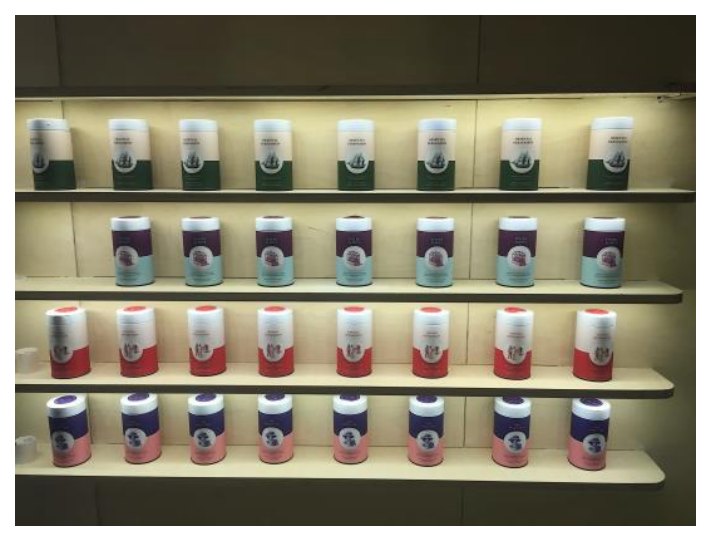

Figure 12. Ironically named tea as a part of an installation being sold at the event.

Next door, was a Zen-style garden designed out of two tonnes of pebbles and marble slabs. The garden follows the topography of the Emerald Hill area. Marble is a "luxury 
stone" and thus suited to a building dedicated to retail. At the same time, the installation was meant to offer shoppers and art-walkers a place of contemplation - we were invited to sit down and were served samples of the teas of the ironic names as a part of the installation.

Leaving the Plaza exhibitions, we headed back outside. The rain had stopped and people were once again on the streets. Back at the school, the pop-up sweet pie shop which had popped-down during the downpour - had reopened and we decided to treat ourselves to cake and elegantly packaged drinks. Sitting and relaxing, we peoplewatched the different types of visitors still arriving in large numbers and discussed how well organised and received the event had been. It catered to expatriates and Singaporeans, young and old, from diverse backgrounds. This was no 'traditional' heritage tour; quite the opposite. It demonstrated a postcolonial critique often missing in Singapore, a critique arising from local arts, culture and heritage practitioners - from local representative cultures both Asian and Western.

\section{Vignette two: Street Art}

Street art has always been a subject of debate. A medium of expression present in plain sight and often considered unsightly, graffiti is an integral part of the urban tapestry. Depending on the subject matter and context, street art is vehemently opposed or encouraged; labeled vandalism or art depending on the temperament of the observer.

In their paper Women on Walls: The Female Subject in Modern Graffiti Art, Katja Fleischmann and Robert Mann (2018, 84), explain that:

Urban centres have always provided the street canvasses and personal battlegrounds for graffiti artists to express their hopes, frustrations and rebellion. The graffiti artist often works in the shadows, out of sight of the norms of society, often at night to escape detection so he or she can inscribe forbidden messages and often symbolically subversive images onto public canvases.

This notion of wall art is problematic in the Singapore context. The public expression of controversial ideas is suppressed in Singapore. Furthermore, anti-establishment propaganda is strictly forbidden ensuring that the city-state remains free of political instability; one of the many strategic methods the government uses to attract and retain foreign investment in the form of money and manpower. Graffiti, comprising drawings scribbled, scratched, or sprayed illicitly on a wall or other surface in a public place, is the 
antithesis of such law and order. However, street art is progressively becoming an integral part of Singapore's urban aesthetic. There are no official records tracing the beginnings of street art and graffiti in Singapore but it is said to have appeared in the mid 1990s. Since then it has garnered mixed reception from the public and government. In the early 2000s when Singapore hosted mega events like IMF-World Bank meetings, Formula 1 and the Youth Olympic Games, graffiti was whitewashed overnight and surveillance increased with the authorities showing zero tolerance for vandalism. With such strict laws on censorship, it is little wonder that the street art and graffiti scene in Singapore has had a turbulent journey to the partial acquiescence it is receiving today. In recent years there is evidence - literally inscribed on the walls - of a more tolerant transition in government attitude. Unsanctioned graffiti on the streets is still considered vandalism and punishable under the Vandalism Act (1966, revised 2014) by a fine or imprisonment, plus caning - but state-sanctioned and endorsed spaces and opportunities have opened up for artists. The ArtScience Museum in Singapore even hosted an exhibition of 'Art from the Streets' around the world, which ran for over three months in early 2018. The Museum furthermore commissioned a series called 'Art on the Street' engaging the local and international street artists Speak Cryptic, Felipe Pantone, and Remi Rough, to produce works beyond the gallery to spaces on the street, including: a bus, a building wall as part of 'ARTWalk Little India' and a site at Gilman Barracks which is a well-known art venue in Singapore (ArtScience Museum, 2018). Even with this softening of attitude, today's wall art scene in Singapore is restricted to sanctioned spaces and compliance within guidelines. This has often resulted in murals depicting publicly accepted nostalgic images and there invoking critique that the government's involvement has commoditised being rebellious.

Walking in the city allows one to explore this new phenomenon of street art in Singapore - and given the critical understanding of how wall art is restricted within state sanctioned guidelines and norms - observe how this art nevertheless reveals 'cracks in the sidewalk' which demonstrate a deviation from the power of panoptic plans. These deviations generally go unnoticed, however, they nevertheless become an inextricable part of people's daily life; wall art as peripheral vision. In Singapore, everyone is constantly on the move. Especially in the civic district and the Central Business District, where people's movements are fueled by consumerist lifestyles and the hyper monetary value of time. These economic motivators are in stark contrast to the ones that propel flânerie. To keep up with the fast-paced lives of people and globalization, the city of Singapore is in a constant state of transformation. This transformation has clearly extended to street art as well. An example of this is the graffiti on a building at the junction of Short Street and Selegie Road in the heart of the arts precinct. 


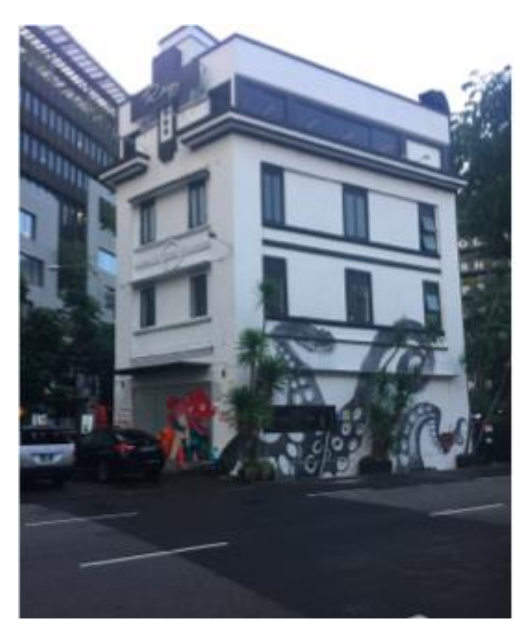

Figure 13. Building displaying wall art in a busy area of the art precinct.

Located in front of an apartment complex catering to international students - including those of the art schools in the vicinity - the building is in the shape of a quadrilateral, narrowed at the front to fit the street intersection. Across the road are two famous old eateries, a Tau Huay stall (Hokkien for tofu dessert) and a Hainan Chicken Rice shop. The angled building is washed in a simple coat of white paint. These white walls have become a canvas for interesting graffiti. On the Short Street side of the three-storey building are painted tentacles protruding from the base of the structure. On the shutters in the front of the building is a painting of an anime girl/woman. Anime is a genre of Japanese film animation and manga graphic novels which have become popular across the world. Long fair limbs, large eyes, sharp features, radical costumes and quirky hairstyles distinguish anime characters. In Asia especially, many anime characters have achieved cult status. Cosplay, humans dressing like anime characters, is also popular in Singapore. 


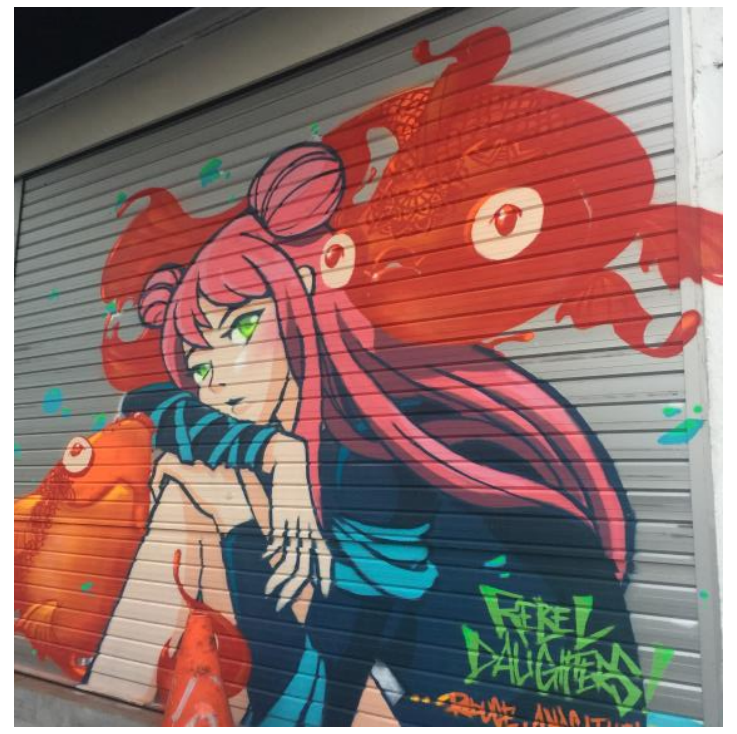

Figure 14. Image of anime woman and the goldfish swimming around her head with henna designs for scales.

This particular anime female is clad in dark blue with light blue ribbons tied around her arms. Her long pink hair is partly tied up in two pom pom buns. She sits, resting her arms and head on her knee, as if perched atop a flight of stairs. There are two goldfish swimming around her. Upon closer inspection, the goldfish have henna-like designs incorporated into their scales - one design in the form of a mandala. The mandala is a symbol of the universe in Buddhism and Hindu spiritual philosophy, while henna designs are traditionally a customary part of the Indian wedding aesthetic. Goldfish which were first bred in China - are very common in Asian imagery and considered to be auspicious according to feng shui, a common practice in the East. This imagery of the anime character, the gold fish and the henna mandala designs are suggestive of the immense cultural diversity that exists in Singapore; the confluence of which creates a unique hybrid space. 

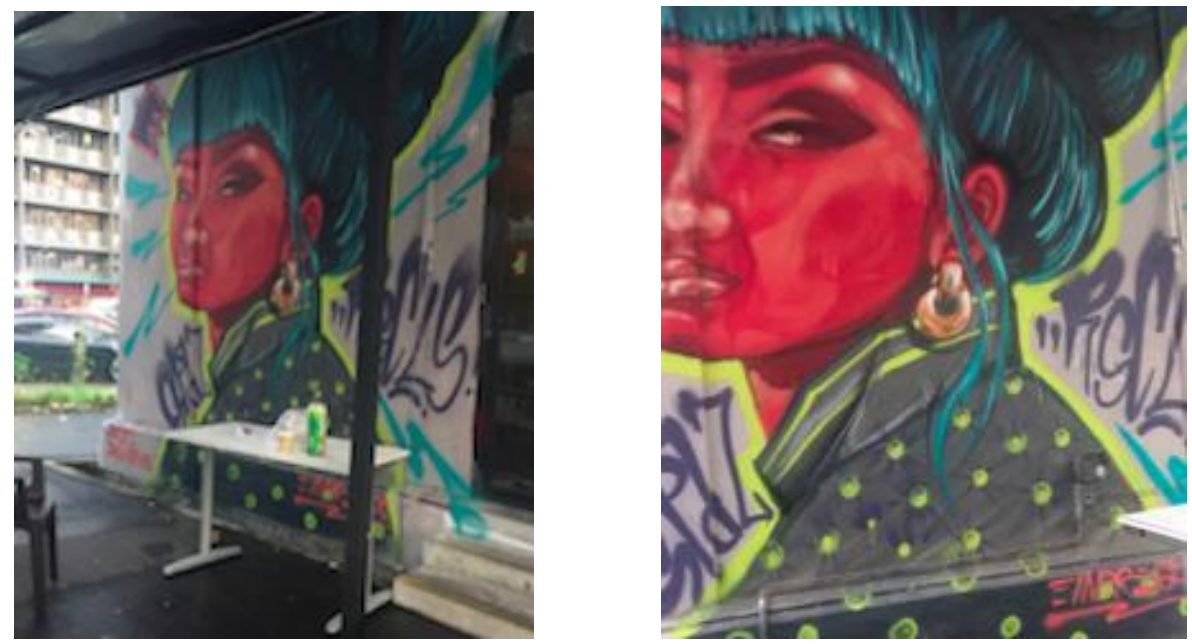

Figures 15 and 16. Wall art on the Selegie Road side of the building.

On the Selegie Road side of the building is a graffiti image of another woman. The tag on the bottom right hand side of the image reads 'EMPRESS'. Again, this is a very feminine image, however, she is fiercer looking than the anime girl. The effect is a look of disdain; or the regal air of an empress. For a practicing flâneuse, her look has an empowering effect - it radiates a confidence highlighted by a sense of pride of her Asian identity portrayed through her clothing. She is dressed in what appears to be a hybrid of traditional clothes interweaving: a high-collared kebaya - a traditional Malay woman's top with a long history traced back to the Javanese Majapahit Kingdom; with a cheongsam (Cantonese) or qípáo (Mandarin) - a traditional Chinese dress especially popularized and modified in the roaring 1920s and 1930s in Shanghai. This is the style of clothing that young people have moved away from in their conscious choice to look 'modern' and global - which is heavily associated with 'Western' consumerism.

The woman's face is painted red, making her look angrier. Her face is framed by a fringe of turquoise-died hair tied up in a bun. This coloring of her hair reflects the changing attitude of younger Singaporeans towards self-expression, recently coming to be demonstrated through the use of bold hair colors - green, blue, purple, pink, orange - especially prominent among arts students that attend the local colleges and hang around this arts district.

The imagery of women on walls, more often than not, symbolizes something deeper and the images are as diverse as the artists who render them. Both these images on the walls have the tag of the artists 'REBEL DAUGHTERS'. The Rebel Daughters have grown into a community and voice for female art practitioners in Singapore. Although 
the Rebel Daughters kicked off with street art and graffiti, women from various other creative disciplines are welcomed to collaborate with the group.

This also brings to the forefront the question of what kind of depictions of women and expressions by women are acceptable in public, and what imagery of women is acceptable to be displayed even as street art. The women portrayed in the graffiti are strong and would catch any passerby's attention. But they are also extremely feminine; a poignant message by the artists which alludes to the fact that a societally prescribed feminine woman continues to be more acceptable - even in the $21^{\text {st }}$ century - when viewed on the streets. In this regard it is also important to note that graffiti and street art are male dominated artistic practices. The idea of women participating in street expression is still controversial. Graffiti, mural and street art are dirty business; scaling tall buildings, sneaking through back alleys and running the risk of being arrested. It is rougher, grittier and darker. There is also the added danger that comes with being out on the streets late at night. However, more and more women are raising their voices to change the discourse and gain equal claim over the streets whether as artists, working women or as flâneuses.

\section{Cracks in the sidewalk}

By using the ethnographic method of flâneuring to explore the metaphorical cracks in the sidewalks through which local creativity may emerge, one of the aims of this paper has been to contribute to the cultivation of a critical, creative discursive milieu. The use of a qualitative method like flânerie allows one to actually engage with creativity, facilitating a deeper investigation of the city's success that can compliment economics and go beyond a reliance on quantitative methods - thus, allowing the addition of another dimension to the discussion regarding Singapore's attempts to become a creative city of the arts.

The case studies in this paper are a testament to how vibrant the 'cracks in the sidewalk' actually are. The case of $\mathrm{OH}$ ! Emerald Hill, in business terms, is a classic example of 'bundling'. Bundling is an important strategy within cultural promotion, it combines a variety of similar themed products and experiences in order to promote their collective consumption to visitors. "Techniques...include art walks (guided and selfguided), gallery crawls or hops, gallery and/or studio tours and studio open days" (McKercher \& du Cros, 2002, p.112). As technical and tedious as the previous definition may sound, the actual event at Emerald Hill was so much more than just a heritage walk; contrary to what one would expect. It was a bold statement and acceptance of the 
tyranny that was the British imperial rule over the colonies. This is a dynamic move especially in Singapore which is distinct from other postcolonial societies in its emulation and glorification of the advancements of the West while forsaking not only many of the political dimensions of democratic life but also its cultural dimensions. As the cultural critic Melissa Wong argues "Colonial subjugation has ironically transferred to a neocolonial one, where influences from the "West," now articulated through the desire to be as economically successful and culturally vibrant as "London or New York," has transferred itself into the fields of identity and cultural production" (2012, p. 242). These case studies showcase local talent and emphasize the importance of heritage allowing one to see not just the cracks, but witness the foundation on which the sidewalks are laid.

When art is utilized as a form of social engineering another aspect that tends to go missing is the element of shock and surprise. This is especially true for graffiti or wall art, the aim of which - as Fleischmann \& Mann (2018, p.84) in this special issue point out, is often to: "shock, surprise, delight and colour in grey and shadowy areas of cities."

While the wall art in Singapore cannot be easily categorised as shocking due to its politically correct and "Instagram worthy" nature; irony lies in the surprising fact of the government's recent acceptance and support of wall art. This is in contrast to the very recent past when any act of graffiti would be considered to contravene the norms and laws of Singaporean society. While this change in tolerance may be another tick box attempt by the government to cultivate a city aesthetics, it is a small step in the right direction and creates the opportunity for more discourse on the matter of street art. Additionally, it is of significance to see how women contribute to this narrative on the streets. While Singapore is one of the safest cities for women in Asia, walking in the city still makes one conscious of their gender and that the freedom to walk the streets is a privilege rather than a right for women. Women 'tagging' the city through art is thus a form of claiming equal rights over the streets.

The common assumption is that Singapore's strict censorship laws would not encourage creativity. However, herein lies the misconception. There are examples in Singapore of how creativity can still be expressed while incorporating and appropriating the larger themes of hyper consumerism, globalization and strict institutional laws. Creativity conceived out of this conflict includes artists turning the concept of consumerism on its head by transforming commercial spaces into alternative venues to share and experience art with an audience. The key to assessing Singapore's success as a creative city is to not restrict oneself to conventional notions of creativity but to be 
open to the arts that manifest despite the institutionally prescribed processes, the results of which can never be planned or anticipated.

\section{Openings (in lieu of closing)}

In this paper we proposed that flânerie offers a method of observing and engaging creativity at the ground level and that the metaphorical cracks in the pavement are the openings through which local creativity may emerge. At a time when cities are undergoing enormous growth, especially pronounced in Asia and across the tropical regions of the world, and are simultaneously being reimagining as spaces reliant upon creative industries and economies, we believe that ethnographic flânerie provides a valuable qualitative method to study and understand these changes, and to document the rise of the creative city.

It is also imperative to keep the assessment of cities culturally relevant. It is well known that previously: "the tropics have been largely defined by the views of outsiders as the region captured the imagination of ancient philosophers and colonial explorers, of artists and scientists." (Lundberg, 2016, p.1). In the case of Singapore, the city needs to move past their emulation of the West in order to focus on and develop a population of people proud of their shared heritage; more emphasis needs to be placed on local talent, including providing equal opportunities to both women and men in the arts and cultural sectors. The development of arts and creativity may however not be a linear process but rather a rhizomatic one; not resulting in success the way it was planned, but rather sprouting fruitful outcomes nonetheless. Singapore's drive to be a global city of the arts is possible, provided it recognizes the ethos of its own community and does not simply try to emulate the cities it has benchmarked itself against. Creating a culturally and artistically authentic city takes time and the actualization of these efforts will take another generation to fully materialize.

The next generation of flâneuses tropigue walking in Singapore a decade from now will experience a very different creative city. We look forward to their ethnographic vignettes. 


\section{References}

ArtScience Museum (2018). Retrieved from: https://www.marinabaysands.com/museum/exhibition-archive/art-from-thestreets.html\#0DvixEdh36R90Zyp.97

Baudelaire, C. (1964). The painter of modern life, and other essays. (Mayne, J., Ed. \& Trans.) London: Phaidon Press.

Benjamin, W. (2003). The Arcades Project. (Eiland, H. \& McLaughlin, K. Trans). Cambridge Mass.: Harvard University Press.

Chaudhury, S. \& Lundberg, A. (2018). Tropical Flânerie \& the Creative Asian City: a perambulation of literature. eTropic: electronic journal of studies in the tropics. 17 (1), 7489. DOI: http://dx.doi.org/10.25120/etropic.17.1.2018.3643

de Certeau. M. (2011)[1984]. The Practice of Everyday Life. Berkley: University of California Press.

du Cros, H. \& Jolliffe, L. (2014). The Arts and Events. London \& New York: Routledge.

Fleischmann, K. \& Mann, R. (2018). Women on Walls: The Female Subject in Modern Graffiti Art. eTropic: electronic journal of studies in the tropics. 17 (2), 83-109.

Hardwick, P. A. 2008. 'Neither Fish nor Fowl': Constructing Peranakan Identity in Colonial and Post-Colonial Singapore. Folklore Forum 38(1), 36-55.

Kong, L. (2012). Ambitions of a Global City: Arts, Culture and Creative Economy in 'Post-Crisis' Singapore. International Journal of Cultural Policy, 18(3), 279-294.

Lundberg, A. (2016). Introduction: A Tropical Lens. eTropic: electronic journal of studies in the tropics, 15 (2), 1-4. DOI: http://dx.doi.org/10.25120/etropic.15.2.2016

McKercher, B \& du Cros, H. (2002). Cultural Tourism: the Partnership between Tourism and Cultural Heritage Management. New York \& London: Routledge Press/The Haworth Press.

Ministry of Information, Communication and the Arts MICA. (2008). Renaissance City Plan III. Published by Ministry of Information, Communication and the Arts. Retrieved from National Arts Council website: https://www.nac.gov.sg/dam/jcr:18cf2883-7907-49389931-384333e210ce

Wong, M. W. (2012). Negotiating class, taste, and culture via the arts scene in Singapore: Postcolonial or cosmopolitan global? Asian Theatre Journal, 29(1), 233-254. Doi10.1353/atj.2012.0026

Yi'En, C. (2014). Telling stories of the city: Walking ethnography, affective materialities, and mobile encounters. Space and Culture, 17(3), 211-223. doi:10.1177/1206331213499468 